\title{
Belydenisuitsprake as Pauliniese briefoorgange
}

\author{
JH Roberts
}

\begin{abstract}
Credal statements as Pauline epistoraly transitions

In view of the fact that I have previously found five occurrances of credal statements in the Pauline literature, the function of which were to effect a transition from letter opening to letter body, the three cases of Romans 1: 16-17, Ephesians 1: 22-23, and Colossians 1: 13-20 were analysed with a view to their credal content and function towards the communication of these letters. The analyses were preceded by a discussion of recent research on credal material in the New Testament.
\end{abstract}

\section{NUWERE NAVORSING OOR DIE BELYDENISASPEK IN DIE NUWE TESTAMENT}

Alhoewel daar enkele besonder belangrike studies oor wat ons breedweg Nuwe-Testamentiese belydenisse kan noem, verskyn het, sal 'n mens tog moet sê dat die veld nog nie ten volle ontgin is nie en om verdere studie vra (vgl egter Cullmann 1943; Conzelmann 1955; Neufeld 1963; Wengst 1967; Hahn 1980; Havener 1981; Gloer 1984). Vir 'n oorsig oor die historiese gang van die ondersoek, vergelyk Wengst (1967: 5-20). Die studie wat hier beoog word, wil enersyds breër, andersyds enger na die vraagstuk kyk as wat in vormhistoriese en tradisiehistoriese studies gedoen is - breër in dié opsig dat daar van belydenisuitsprake en nie van belydenisse of belydenisformules nie, gepraat word; enger in dié sin dat daar alleen gevra word na sulke belydenisuitsprake in die Pauliniese briewe, en dan met name in die openingsgedeeltes van die briewe tussen briefaanhef en briefsentrum, waar dit as oorgange na die briefsentrum (of -liggaam) funksioneer (vgl Roberts 1986a).

Die terminologie wat in die literatuur in verband met die belydenisaspek in die Nuwe Testament gebruik word, is nie eensluidend nie en werk verwarrend. Zimmermann (1968: 162-163; 169-172) onderskei 
tussen belydenisse ('Bekenntnisse'), wat liturgiese tradisiestof sou wees, homologieë en geloofsformules. Laasgenoemde twee word onder die opskrif van 'formules' behandel.

Uit die behandeling blyk dit egter dat albei soorte tog ook in die liturgie funksioneer, enersyds as akklamasie, andersyds as die 'belydenis' van die dopeling by sy opneming in die gemeente. Gloer (1984) hou nie rekening met dusdanige onderskeidings nie (hy ken blykbaar nie die werk van Conzelmann 1955 of van Hahn 1980 nie) en behandel die belydenisstof onder die noemer 'homologie'. Hiernaas gee hy dan aandag aan die liedere ('hymns') wat ook 'n belydenisagtige karakter vertoon. Dat die liedere in dié verband belangrik is, en wat hulle verhouding tot belydenisse is, sal aanstons uit die bydrae van Hahn (1980) gesien kan word.

Intussen blyk die onderskeidings van Conzelmann (1955) van besondere belang te wees. Alhoewel alle probleme daarmee nie opgelos is nie, en veral die keuse van die terminologie bevraagteken kan word, is dit nie moontlik om agter hierdie stofverdeling terug te gaan nie. Aan die een kant is daar volgens hom die homologie - 'n kultiese akklamasie en proklamasie van die teenswoordige posisie en status van Jesus in die midde van die versamelde gemeente. Dit bestaan uit ' $n$ verbinding van die persoon van Jesus met ' $n$ titel, hetsy Kurios, Christus, of Seun van God. Aan die ander kant onderskei hy die credo, waar dit nie om akklamasie gaan nie, maar waar die klem op die leerstof val wat geglo word. Hierdie tipe word dan ook soms ingelei met die vermelding daarvan dat dit is wat die gelowiges glo, dit wil sê, die dinge waarvan hulle oortuig is, wat hulle vir waar hou. Hierby gaan dit om die reeds gebeurde, om die verlede heilswerk van God in die persoon en werk van Jesus, waarby met name sy sterwe en sy opwekking uit die dood, oftewel sy verhoging, op die voorgrond staan. Naas hierdie twee hooftipes lei die konfrontasie met die heidendom (= veelgodedom) tot ' $n$ belydenis met twee artikels wat beklemtoon: Daar is maar een God en een Here. Binne-kerklike konfrontasies (die gnostiek) lei tot geloofsafgrensing sodat die belydenis tot regula fidei word; en die uitbly van die paroesie tot die ontstaan van die epifanieformule wat uitdrukking gee aan die vroeëre verborgenheid van die heil, die huidige geopenbaardheid daarvan, en - op grond hiervan - die teenswoordige verkondiging van die heil.

Hahn (1980) sluit hom by die hoofonderskeiding van Conzelmann aan, maar met gebruikmaking van die term geloofsformule ('Glaubensformel'). Die volgende aanhalings uit hierdie werk maak nie net die 
posisie besonder duidelik nie, maar stel ook die verhouding tussen homologie en geloofsformule met besondere klaarheid.

Neben dem 'Bekenntnis' im engeren Sinne der homologia mit seiner akklamatorischen Funktion steht im Neuen Testament die 'Glaubensformel'. Das Bekenntnis bezieht sich stets auf den erhöhten und lebendigen Herrn in seiner gegenwärtigen Stellung und Funktion: Er ist der Herr, der Christus, der Gottessohn: Die Glaubensformel redet primär in der Vergangenheit: Sie blickt zurück auf das was geschehen ist (Hahn 1980: 207).

Das Bekenntnis mit seinem proklamatorischen und rechtsverbindlichen Charakter erhält mit der Glaubensformel eine konkrete inhaltliche Füllung, eine spezifische Näherbestimmung. In der Glaubensformel geht es um das, was Gott in Christus zu unserem Heil getan hat und noch tun wird. Im Zentrum steht dabei das Osterereignis in Verbindung mit dem Sterben Jesu; um deises Zentrum Tod und Auferstehung stehen dann gleichsam wie bei konzentrischen Kreisen die Aussagen über die Sendung und Menschwerdung Jesu und über Jesu Wiederkunft. Mit der Glaubensformel wird die Basis für das Bekenntnis, nämlich Gottes eigenes Handeln in Christus, aufgezeigt. Das mit dem Munde formulierte Bekenntnis muss im Herzen gleichsam untermauert sein, bezogen auf den Glaubensgrund, der in der Glaubensformel kurz zusemmensgefasst ist (Hahn 1980: 208).

Die vasstelling van Conzelmann (1955: 73-74) dat gebeurtenisse binne die kerk, soos die stryd teen dwaling of die uitbly van die paroesie, gelei het tot nuwe formulerings wat ook vaste vorms kon aanneem soos in die geval van die epifanieformules, of soos dit in liedere neerslag gevind het, is vir dit wat hier aangebied word van besondere gewig. Immers, wat hier met die formering van formeel min of meer vaste vorme gebeur het, moet in haas elke nuwe situasie gelei het tot die ad hoc formulering van informele belydenisuitsprake. Dit wil sê dit geld in gevalle waar daar nie ' $n$ vaste vormgewing aan die uitspraak gekoppel is nie, alhoewel dit sekerlik ook kon gebeur het dat daar vir dié doel formule-elemente in so' $n$ uitspraak opgeneem kon word. Die kontensie van die betoog wat hier gevoer word, is dat Paulus soms presies op hierdie manier ' $n$ belydenisuitspraak formuleer om aan die begin van 'n brief, as 'n soort argument by voorbaat, 'n oorgang te vorm tot die saak of ' $n$ saak wat in die briefliggaam uitgewerk sal word.

In dié verband is dit van belang om, voordat ons voortgaan om aan 
die spesifieke onderwerp van hierdie studie aandag te wy, allereers nog aan twee gesigspunte uit die werke van Conzelmann en Hahn aandag te gee. Dit sluit enersyds aan by die stelling wat so pas hierbo gemaak is, en bied andersyds ' $n$ belangrike vooruitskouing op wat verder aan, veral ten opsigte van Kolossense, uitgewerk gaan word. Met name gaan dit hier om gesigspunte betreffende die verhouding van die himnes of liedere tot die belydenisse.

Dit is duidelik dat Conzelmann (1955: 71) die liedere streng van die belydenisse onderskei soos die volgende aanhaling bewys:

Auch die Lieder handeln vom Erlöser und dem Vorgang der Erlösung. Aber der Sitz im Kult ist von dem des Bekenntnisses verschieden. Das Lied kann im Kult die Akklamation vorbereiten, was man daran sieht, das man Lieder in eine Homologie münden lässt; das trefflichste Beispiel haben wir gerade an der oben genannten Stelle. (Die verwysing is na Fil 2: 6-11 - JHR.)

Meer genuanseerd is Hahn (1980: 210-212) se standpunt oor die himnes, waarvan hy sê (1980: 210):

Es handelt sich um ausgebaute, rhythmisch durchstrukturierte Glaubensformeln.

Die onderskeiding tussen die Christologiese belydenis, dit wil sê die homologie, die geloofsformule en die himne, stel hy (1980: 212) soos volg:

Wir stellten fest, dass die Glaubensformeln das christologische Bekenntnis im Sinn der Akklamation durch den Hinweis auf das Heilshandeln Gottes in Christus begründen und explizieren. Entsprechend will gerade auch der Himnus als eine Explikation des Bekenntnisses verstanden werden; und der Lobpreis der Gemeinde soll hinführen zu der immer wieder neu laut werdenden Homologie 'Herr ist Jesus Christus'.

$\mathrm{Na}$ hierdie besonder insiggewende insigte van Hahn sal ons later moet terugkeer in samehang met sy insigte oor belydenis en teologiese uitbouing met betrekking tot Romeine, terwyl ons ook die geleentheid sal hê om weer aandag te gee aan die stellings van beide Conzelmann en Hahn in verband met himnes wat uitmond in ' $n$ homologie, wanneer ons Kolossense 1 behandel. 
In my bespreking van die briefoorgange in die Metzgerfeesbundel (Roberts 1986a) het ek vyf gevalle waar geloofsuitsprake in die oorgangsgedeeltes voorkom, geïdentifiseer, te wete Romeine 1: 16-17, 1 Korintiërs 1: 8-9, Efesiërs 1: 22-23, Kolossense 1: 13-20 en 1 Timoteus 1: 15.1 Timoteus 1: 15 word hier buite rekening gelaat omdat die brief op hierdie punt formeel heeltemal afwyk van die gebruiklike Pauliniese vorm, en ons in werklikheid nie meer van 'n oorgangsgedeelte kan praat as die brief reeds in 1: 3-11 met die deur in die huis geval het en daarna in 1: 12 met 'n - in elk geval ongewone - vorm van danksegging voortgaan nie. Oor 1 Korintiërs 1: 8-9 het ek elders gehandel (Roberts 1986b): Hoewel daar in hierdie gedeelte belydenisstof voorkom, is dit tog duidelik dat ons hier veeleer met 'n eskatologiese uitspraak (eskatologiese klimaks) te doen het. Dit word dus hier nie weer aan die orde gestel nie. Wat Romeine 1: 16-17, Efesiërs 1: 22-23 en Kolossense 1: 13-20 betref, moet hier volstaan word met die aanduiding van die belangrikste aspekte terwyl daar aan baie detail verbygegaan word.

\section{DIE BELYDENISUITSPRAKE IN ROMEINE, EFESIËRS EN KOLOSSENSE}

\subsection{Romeine 1: 16-17}

$\mathrm{Na}$ die aanhef van Romeine kry ons in 1: 8-10, 1: 11-15 en 1: 16-17 tipies drie afsonderlike oorgangsparagrawe (vergelyk Roberts 1986a: $192,197)$. In die eerste twee, 'n gekombineerde danksegging/gebedeseksie en 'n gedeelte wat onder persoonlike opmerkings ressorteer, word daar na Paulus se voorgenome besoek aan Rome verwys en is die funksie hiervan die bewerking van vriendskapsrelasies en simpatie van die lesers teenoor die skrywer (vergelyk Koskenniemi 1956). Die derde bevat die belydenisuitspraak waarop ons interesse hier fokus.

Dat Romeine 1: 16-17 'n besonder belangrike rol in dié brief speel, word algemeen erken. Dit word dikwels as die tema van die brief aangedui (Dodd 1959: 37; Käsemann 1973: 18-32; vergelyk ook, maar met genuanseerde aanvaarding, Ridderbos 1959: 32; Michel 1963: 56; verder oor die brieftema Pelser 1984: 41). Wat die oorgangsfunksie van hierdie belydenisuitspraak is, het ek in die bogemelde artikel (1986a: 197) kort in die volgende stelling saamgevat: '. . . the credal statement has the function of determining the essential core of the argument to be made in the letter.' Sonder dat hy blyke gee van enige interesse in, of kennis van, formele oorgangsgebruike, of van 'n dergelike funksie ten 
opsigte van 1: 16-17, het Hahn (1980: 212) met klare insig daarin geslaag om inhoudelik presies hierdie aspek duidelik na vore te bring.

Eerstens toon hy aan (wat ek in my artikel nie raakgesien het nie) dat daar ' $n$ noue verband bestaan tussen 1: 1-4 en 1: 16-17. Dit bestaan enersyds in sy opdrag as apostel ten opsigte van die evangelie en andersyds in die ontvouende aansluiting van 1: $16-17$ by die Christologiese formule van 1: 4. Tweedens bevestig hy wat ek hierbo ten opsigte van die ad hoc formulering van geloofswaarhede na gelang van diverse omtandighede gestel het. Allereers is van belang sy vasstelling dat, by alle binding aan die beslissende belydenisgrondslae, juis die feit dat daar verskillende vorme van die basiese belydenis (? lees homologie) voorgekom het en dat daar verskillende weergawes van die geloofsuitsprake (? lees Glaubensformeln) bestaan het, tot die konklusie lei dat die belydenis onvermydelik roep om herinterpretasie en om gewysigde vormgewing. Voorts bied juis die Romeinebrief volgens hom 'n besondere voorbeeld van hoe die geloofsformules en himnes se ontvouing van die basiese belydenis, 'in Verkündigung und Theologie in freier und aktueller Weise' (Hahn 1980: 212) ' $n$ voortgesette uitbouing meegemaak het. Hier moet eers herinner word aan die feit dat 1: 1-4 Paulus se geroepenheid om die evangelie te verkondig, beklemtoon en dan, om hierdie evangelie nader te verduidelik, aansluit by die Christologiese formule.

In die lig hiervan formuleer Hahn (1980: 212) dan die volgende stellings:

Die christologische Formel wird nun von Paulus in der Themenformulierung Röm 1,16f soteriologisch entfaltet mit Hilfe der Rechtfertigungslehre; und was an dieser Stelle zunächst einmal thematisch in einer überaus kompromierten Weise zum Ausdruck gebracht ist, wird dann im ganzen nachfolgenden Römerbrief näher ausgeführt.

Die in Röm 10,9 ausdrücklich zitierte homologia 'Herr ist Jesus' wird also zu Beginn des Briefes mit jener Glaubensformel aufgenommen und im folgenden theologisch expliziert. So interpretiert Paulus inhaltlich das Evangelium von Jesus Christus. Der Dreischritt Bekenntnis, Glaubensformel und soteriologische Interpretation will beachtet sein.

Wat Hahn hier as die soteriologiese interpretasie beskryf en deur my as ' $n$ belydenisuitspraak aangedui is, vervul inderdaad die funksie om as 'n kort stelling te dien van die hoofsaak waarom dit in die brief sal 
handel. Enersyds sluit dit aan by die briefaanhef ten opsigte van Paulus se opdrag om die evangelie aan die heidene te verkondig, asook by die twee voorafgaande gedeeltes wat sy begeerte om in hierdie opsig ook aan die gemeente in Rome diensbaar te wees, onder woorde bring. Die litotes in 1: 16 stel dit sterk: Paulus verkondig graag die goeie boodskap. Andersyds sluit dit aan by die belydenisinhoud in 1:3-4 en die gedagtes in 1: 5-7 wat daarmee saamhang. Die goeie boodskap is die boodskap oor Jesus Christus en die heil wat God in Hom vir Jode en heidene bewerk het en wat hulle deel word deur te vertrou op die heilsboodskap, in feite op God en sy Gesalfde.

Hieroor inderdaad gaan dit in hierdie brief: oor die goeie boodskap; oor die feit dat dit die heilsboodskap is vir Jode en vir Grieke; oor die feit dat God die skeefgeloopte verhouding tussen Hom en die mense weer reggestel het; oor die redding wat dit meegebring het; en oor die feit dat hierdie heil slegs langs die weg van vertroue die mens se lewe binnekom.

\subsection{Efesiërs 1: 22-23}

Hierdie verse word gewoonlik verstaan as ten nouste verbonde aan 1: 20-22, en 1: 20-23 dan weer as onderdeel van wat verkeerdelik die danksegging genoem word (Lindemann 1975: 204). Pogings om die gedeelte as himne te klassifiseer is meermale aangewend (Sanders 1965: 220-223, 232; Barth 1974: 6-10, 153-156; Barth 1984: 9), maar is nie geslaagd nie (Lindemann 1975: 205; Schnackenburg 1982: 70-71). Dat ons hier wel met belydenisstof te make het, dit wil sê met tradisionele materiaal, hetsy in verbrokkelde vorm of as uittreksel, of andersins as eie komposisie van die outeur, maar met gebruikmaking van ouer materiaal, word tereg in wye kringe aanvaar (Schlier 1958: 86; Conzelmann 1962: 63; Gnilka 1971: 93-99; Barth 1982: 163-164; Schnackenburg 1982: 84; vgl ook Lona 1984: 313-321).

Met hierdie laasgenoemde standpunt is ek dit sonder meer eens, maar verskil in een belangrike opsig van die gangbare literatuur. Waar die algemene standpunt uitgaan van die eenheid van 1: $20-23$ as onderdeel van 1: 15-23, meen ek dat $1: 22-23$ as 'n afsonderlike oorgangsparagraaf dien wat die karakter van 'n belydenisuitspraak vertoon (Roberts 1986a: 198-199). Hiermee word nie ontken dat 1: 20-21 tradisionele belydenisstof bevat nie en ook nie dat daar 'n noue verband tussen verse $20-21$ en $22-23$ bestaan nie. In hierdie besondere geval vervul die oorgangsparagraaf 'n tipiese skarnierfunksie, waar die 
eerste been van die belydenisuitspraak sterk terugverwys na die direk voorafgaande en saam daarmee belangrike aanduidings bevat van motiewe wat vorentoe in die brief 'n wesenlike rol gaan speel, terwyl die tweede been van die belydenisuispraak sterk na vore strek en eweneens op komende motiewe aanspeel.

Wat die afsonderlikheid van 1: 22-23 betref, moet die volgende opgemerk word (vergelyk ook Roberts 1983: 50-56). Wanneer 'n mens eenmaal daarop bedag is dat die Pauliniese groep van briewe verskillende en formeel sterk onderskeie vorme van gebedsverslae aanwend om as een van die openingselemente van die briewe te funksioneer (Roberts 1986a: 191-192), is dit nie langer moontlik om nog in al die gevalle van 'n openingsdanksegging te praat nie. In die gekombineerde vorm van danksegging plus voorbidding wat in 1: 15-21 aangetref word, is die uitdrukking van dank wel belangrik, maar dien dit wesenlik as inleiding tot die verslag van die katalogus van petisies wat hier die hoofklem dra en wat in twee, meer algemene, formele, en ' $n$ groep meer spesifieke, inhoudelike bedes of versoeke ingedeel kan word (1: 17-21, vergelyk Roberts 1983: 46-50). Die derde van hierdie versoeke (1: 19a) pleit dat die lesers mag leer verstaan hoe groot die krag van God is wat werk in diegene wat glo. Sintakties is verse 19b-21 'n inbedding by die voorafgaande wat die grootheid van God se kragwerking in perspektief stel deur dit te vergelyk met daardie ander magtige, heilshistoriese magsontplooiing wat God in die Gesalfde bewerk het toe Hy Hom uit die dood opgewek het en die hemelse heerskappy aan Hom verleen het. Die inbedding is dus nog wesenlik deel van die derde petisie, dit wil sê, van die gekombineerde dankseggings- en gebedsgedeelte. Die lesers moet besef: Dit is inderdaad die opstandingskrag wat in die opwekking van Christus ontplooi is, wat God ook in die gelowiges tot ontplooiing wil bring.

Hierdie situasie (die sintaktiese inbedding) verander radikaal by 1 : 22-23. Sintakties het ons hier met nuwe kolons te make - selfstandige seggings met eie naamwoorddeel en werkwoorddeel en wat nie meer deel van die voorafgaande vergelyking uitmaak nie. Dit is daarom ook op geen manier meer deel van die voorafgaande petisies nie en maak nie langer deel uit van die gekombineerde dankseggings/gebedsdeel nie. Die vraag is: Wat is dit dan? In ooreenstemming met die gebruiklike Pauliniese patroon kan daar na die dank en/of gebedsverslag op hierdie punt, en voor die aanvang van die briefsentrum, een of meer selfstandige perikope verwag word wat die spesifieke funksie vervul om 'n oorgang na die briefliggaam te bewerk (Roberts 1986a: 192). 
Kommunikasiegewys lê die saak wat die skrywer aan sy lesers wou oordra in die drievoudige verduideliking in hoofstuk 2 van wat hulle nuwe verhouding tot die Gesalfde vir hulle beteken en die uitwerking daarvan vir die praktyk van die kerklike en persoonlike lewe wat in hoofstukke 4-6 nader aangedui word. Van hieruit besien, neem die briefliggaam in 2: 1 sy aanvang, en moet in 1: 22-23 'n oorgangsparagraaf tussen die petisies en die briefliggaam gesien word.

Die vraag wat oorbly is dié na die aard van die perikoop, na die spesifieke oogangstegniek wat hier aangewend word. Lindemann kan met ' $n$ mate van reg hierdie verse as 'n samevatting van 1: 20-21 tipeer (1975: 211). Tog bevat hierdie verse meer as wat in 20-21 aan die lig kom. Die verse bevat stellings - twee stellings wat drie dinge wil sê, om presies te wees: (1) God het alle dinge aan die Gesalfde onderwerp; (2) die Gesalfde is die heerskapshoof oor alle dinge; (3) God het Hom, hierdie heerser oor alles, aan die kerk, die volk van God, gegee. Dit is duidelik dat die drie sake lê op die terrein van die Teologiese (pregnant bedoel), die Christologiese, die kosmologiese en die ekklesiologiese, asook, by nadere insiens, op grond van die presiserende kwalifikasies van die kerk in vers 23 (kyk onder), op die terrein van die soteriologie. Met stellings wat op hierdie terreine beweeg, het ons natuurlik te doen met die essensie van dit waarom belydenisse opgebou is en kan hierdie verse nou ook met beslistheid as belydenisuitspraak getipeer word. Die kai waarmee dit begin, moet emfaties verstaan word (vergelyk Dana \& Mantey 1927: 250-251), eerder as epeksegeties (Lindemann 1975: 212): Die belydenisuitspraak stel die voorafgaande met groot klem, eerder as om dit net saam te vat: 'Inderdaad - Hy het alles onder sy voete gestel!'

Soos in die geval van Romeine 1: 16-17 hierbo, is dit nie hier die geleentheid om op die detail van die belydenisuitspraak in te gaan nie. Waaraan ons wel aandag moet gee, is die formele binding met die briefliggaam, met ander woorde die vraag na die funksie van hierdie belydenisuitspraak, die vraag na hoe dit die saak wat die brief wil kommunikeer, by voorbaat aan die orde stel. In die Metzgerfeesbundel het ek hieroor in die algemeen geskryf: 'It provides the basis for the main argument of the letter provided by the three pericopae of chapter 2' (Roberts 1986a: 199). Hoe lyk die besonderhede?

Formeel en saaklik sal 'n mens die drie aspekte wat hierbo aangetoon is, as twee bene van hierdie belydenisuitspraak moet aandui: Vers 22a bevat die Teologiese en Christologies-kosmologiese belydenis van die Gesalfde se volstrekte heerskappy oor alle dinge; verse $22 b-23$ die ekklesiologies-soteriologiese belydenis oor die kerk se wesensverhou- 
ding tot die Gesalfde soos deur God bewerk. In hierdie brief gaan dit om die kommunikasie van 'n boodskap wat hoofsaaklik as die teologiese en etiese uitbouing van die tweede been beskou moet word; in die proses word daar egter telkens teruggegryp op die eerste been. Per slot van sake het ons hier met twee bene van een geloofsuitspraak te doen wat nie van mekaar geskei kan word nie. Omdat dit in hoofsaak om die tweede element draai, word dit hier as uitgangspunt van die bespreking geneem en na die eerste verwys waar dit ter sake is.

In die algemeen blyk die belang van die belydenisuitspraak vir die briefinhoud uit die relasie wat ek tevore (Roberts 1983: 15-19; 50-56) aangedui het. God se heilsgawe aan sy kerk, die Gesalfde wat sy heil bewerk het, beteken vir die nuwe gelowiges aan wie die brief gerig is, dat hulle: (1) nie meer dood is nie, maar lewe (2: $1-10)$; (2) nie meer ver is nie, maar naby gekom het (2: 11-18); (3) nie meer buitestaanders is nie, maar God se gesin of familie, lede van sy verbondsvolk, geword het (2: 19-22).

Die manier waarop God, of die Gesalfde, alles in elke opsig volledig uitgevoer en afgehandel het om so die heil vir sy mense te bewerk (1: 23 ), word in 2: 1-10 slegs by wyse van suggestie aan die sterwe van die Gesalfde gekoppel wanneer dit sê dat God ons saam lewend gemaak het in die Gesalfde - só eerder as die lesing 'met Christus' (vergelyk die alternatiewe lesing van 'n sterk groep getuies). Hieragter lê die gedagte van die Gesalfde wat as Representant die gelowiges in sy sterwe en opstanding aan sy heilsdaad verbind het en hulle by Hom geinkorporeer het. Die volledigheid van die heilsbewerking word hier na vore gebring in die bevestiging dat hulle ook saam met Hom opgewek is, ja, ook in Hom saam in die hemel sit (2: 5-6). Met hierdie laaste gedagte word die aandag terugverskuif na die eerste been van die belydenisuitspraak. Christus is die oorwinnaar wat as kosmiese Heerskappyvoerder oor alles troon (1:22). Dit is in 1: 20 simbolies uitgedruk in die beeld van sy sitplek aan die regterhand van die Vader. In verbondenheid aan Hom en op grond van sy heilswerk, is die gelowiges ook in sy oorwinning oor die magte van boosheid betrek (vergelyk ook Allen 1986: 103-120).

In 2: 11-18 figureer die tweede been van die belydenisuitspraak weer eens sterk, en dié keer uitsluitlik. Die heil is vir die gelowiges ten volle bewerk deur hulle gerepresenteerdheid in die kruisdood van die Gesalfde, waardeur versoening tussen hulle en God as hulle Vader tot stand gebring is. Maar versoening met God beteken ook onderlinge versoening van die gelowiges wat in een liggaam, die liggaam van 
Christus, met God versoen is. As gerepresenteerdes deur die Gesalfde is hulle as sy liggaam by Hom in sy heilsdaad geïnkorporeer. As lede van hierdie liggaam is hulle oor die grense van Jodedom en heidendom heen, met mekaar en met God versoen.

In die volgende perikoop (2: 19-22) word die gedagte van 2: 11-18 voortgesit met gebruik van ' $n$ ander stel beelde en voorstellings. Die teruggryping na 1: 22-23 geskied egter slegs in die algemene terme wat hierbo geskets is. Dieselfde is waar van 3: $1,14-19 ; 3: 2-13$ en 3: $20-21$, alhoewel ons hier ' $n$ heropneming aantref van die struktuurelemente: liggaam van Christus (3: 6) en verbondsvolk van God (ekklessía: 3: 10 en 3: 21), asook van die gedagte dat die gelowiges, as resultaat van die verhoring van die gebed, heeltemal vervul sal wees met die volheid van die heil wat van God af kom (3: 19).

Dit is egter veral in die paranetiese gedeelte wat in sy geheel sterk teruggryp op die kommunikasie-elemente in 1-3 dat die aansluiting by 1: 22-23 duidelik blyk. Dit gaan hier immers om die nuwe lewe van die kerk en van die gelowige wat onder die bewind van die Oorwinnaar gevoer word: Vergelyk veral die heropname van die triomf van die opgestane Heer in 4: 7-11, 16. Dit gaan hier egter ook om die een kerk wat uit Jode en heidene tot stand gekom het op grond van die Gesalfde se heilswerk en waarvan die eenheid gehandhaaf moet word (4: 1-6), en met alle gawes van die verhoogde Heer gedien en as liggaam van Christus opgebou moet word (4: 7-16).

\subsection{Kolossense 1: 13-20}

Dat ons in Kolossense 1: 15-20 met 'n lied van die een of ander aard te doen het, word in die literatuur algemeen aanvaar (vgl Botha 1986: 238), hetsy ' $n$ lied oorgeneem uit die tradisie, met die aanname van 'n vroeër nie-Christelike oorspronklike (Käsemann: [1949] 1960), of daarsonder (Lohse 1977: 79), hetsy 'n eie komposisie van die outeur (Ridderbos 1960: 151) - 'n lied met twee strofes (Schweizer 1980: 52), of met drie (Martin 1972: 44-49), of een met twee strofes en 'n refrein wat tussen die twee voorkom (McCown 1979: 158-162), of dan met 'n oorgangspassasie wat van strofe een na twee lei (Bruce 1984: 100), of, ten slotte, ' $n$ lied in die vorm van ' $n$ palindroom, opgebou rondom vers $17 \mathrm{~b}$ as sentrale en koördinerende moment (Baugh 1985).

Dit sal uiteraard nie moontlik wees om hier op al die vraagstukke wat met die bostaande gemoeid is, in te gaan nie. Tog sal, sonder om 'n 
uitgebreide redevoeringsanalise aan te bied, aandag aan aspekte van die struktuur en funksie van 1: 13-20 gegee moet word.

In die teks soos dit voor ons lê, moet dit duidelik wees dat die hós wat in vers 15 en $18 \mathrm{~b}$ volgens baie die parallelle strofes inlui, 'n ewe belangrike struktuuraanduiding ten opsigte van vers 13 en 14 bevat. Dit is nie moontlik om op grond van die inleidende hós as aanduiding van liturgiese stof (vergelyk Norden 1956: 168-176, 201-207, 383-387; vergelyk ook Gloer 1984: 128) vir die himnekarakter van 1: 15-20 te redeneer sonder om dieselfde argument ten opsigte van vers 13 en 14 te laat geld nie (vergelyk ook Vawter 1971: 74-75, wat met Käsemann [1949] 1960: 38, vers 12 daarby betrek). Bowendien moet in gedagte gehou word dat wanneer hós 'n selfstandige kolon inlui soos wat hier in al drie die gevalle gebeur, dit nie 'n relatiewe funksie vervul nie, maar in wese as sinoniem vir autós optree. In die lig daarvan dat autós vers $17 a$ en 18a inlui, mag ' $n$ mens jou sekerlik nie blind staar teen die inleidende hós as strofe-aanduiding by vers 15 en $18 \mathrm{~b}$ nie.

Op hierdie punt sal ek nou graag wil terugverwys na die opmerking van Conzelmann (vergelyk hierbo bl 84 ) dat ' $n$ lied by geleentheid kan uitmond in 'n homologie. Hier, by 1: 13-20, sal 'n mens kan redeneer dat die teenoorgestelde gebeur, naamlik dat ons in 1: 13-14 ' $n$ belydenisuitspraak het wat oorloop in ' $n$ lied. Hierby sal die vraag dan egter ook gevra moet word of die lied hiermee nie wesenlik tot belydenis geword het nie (vergelyk die bespreking van die lied as draer van Christologiese inhoud en ontwikkeling by Hengel 1983; vergelyk verder Vawter 1971: 69, 75).

Vra ons na die plek van 1: 13-20 in die raamwerk van die brief aan die Kolossense, tree 'n dergelike verskynsel as in die geval van Efesiërs na vore. Verse 13-14 maak kennelik nie meer deel uit van die voorafgaande stuk voorbidding nie. Hier word nie meer gebid nie, maar word die geloofsoortuigings van die vroeë kerk bely. 'n Mens sou vir 'n oomblik met Käsemann ([1949] 1960: 38) kon oorweeg of vers 12 nie by verse 13-14 hoort nie, maar die argumente oortuig nie - moet ten dele ' $n$ uitsonderlike gebruik van eucharistoûntes veronderstel en ten dele 'n onbewese tekslesing aanneem. Vers 12 is duidelik nog 'n by-die-bedes-ingebedde gedagte, terwyl vers 13 , met die kenmerkende liturgiese hós-inleiding, nuwe selfstandige seggings inlui wat in die vorm van stellings die gemeente se geloofsgoed verwoord (so ook Käsemann [1949] 1960: 37). Wat verse 15-20 betref, lyk dit my asof die vraag of hier werklik'n lied aangehaal word, nog steeds nie voldoende aangetoon is nie. Dat hier tradisiestof voorhande lê, lyk my wel 
duidelik. Maar, terwyl daar 'n feitelike konsensus bestaan oor die teenwoordigheid hier van 'n lied, loop die gedagtes oor die strofering en poëtiese vormgewing nog steeds so wyd uiteen, dat ten minste die kritiese bevraagtekening van die konsensus nie agterweë behoort te bly nie. Het ons hier wel met 'n lied te doen (vergelyk ook Barkhuizen 1985: 20), moet die poëtiese gehalte daarvan met Baugh (1985) in die semitiese parallelisme eerder as in metrum gevind word. (Sy poging om verse $15-20$ te lees as ' $n$ chiasme - eintlik volgens sy indeling ' $n$ palindroom - wat hy as die eintlike kenmerk van Hebreeuse poësie aandui (1985: 232), vind ek te gedronge om oortuigend te wees.) In die lig van hierdie oorwegings lyk dit my verstandiger, en vir die uitleg van die brief sekerlik meer funksioneel, om die hele stuk, die belydenisuitspraak in 1: 13-14, en die lied, of wat dan ook, wat met sy duidelike belydenisinhoud daaraan toegevoeg is (1: 15-20), as 'n stuk belydenis te benader en te vra na enersyds die inhoud daarvan en andersyds die funksie wat dit as belydenisstuk ten opsigte van die brief as geheel vervul.

Die belydenisinhoud van 1: 13-20 omvat drieërlei:

- Die heilshistoriese, epogmakende heilshandelinge van God wat die redding van die belyers bewerk het. Die redding beteken ' $n$ oorgang uit die ryk van die duisternis na die ryk van God se geliefde Seun. Dit beteken om nie langer onder die bewind van die duisternis te leef nie, maar om oorgeplaas te wees onder die bewind van die geliefde Seun (vers 13).

- Die heilservaring van die belyers (vers 14). Op grond van hulle verbondenheid aan die Geliefde beleef hulle God se heilsdaad as ' $n$ bevryding, ' $n$ toestand wat op sy beurt beskryf word as die vergifnis van sonde.

- Die status van die Seun (vers 15-20). Dat God se heilsdaad uitloop op die epog van die heerskappy van die Seun en dat die belyers die heil ervaar op grond van hulle verbondenheid aan die Seun, lei tot die vraag na die status van hierdie Seun. Die vraag word beantwoord deur na die Seun te kyk in terme van drie verhoudings. Die belydenis wil ' $\mathrm{n}$ antwoord gee op die vraag: Wie is $\mathrm{Hy}$ ? Wie is $\mathrm{Hy}$ wanneer daar na Hom gekyk word vanuit die verhouding tot God (1: 15a), vanuit die verhouding tot die skepping (1: 15b-17), en vanuit die verhouding tot die kerk (1: 18-20).

Hoe word die status van die Seun hier in hierdie drie verhoudings beskryf? Uiteraard kan ook hier slegs aangestip word: 
- Die Seun se status, gedefinieer in verhouding tot God (1: 15a), is dié van eikōn, beeld van die onsigbare God, waarmee ongetwyfeld uitgedruk word dat Hy die draer is van die wesenseie van God. Dit slaan sekerlik nie alleen op die inkarnasie nie, maar verklank tog die gedagte dat die wese van dié God wat nie gesien kan word nie, in die Seun tot openbaring kom en toeganklik word (vergelyk Bratcher \& Nida 1977: 22; Ridderbos 1960: 135-137).

- Ten opsigte van die skepping word die status van die Seun omskryf as eerste in rangorde (1: 15b, 17a). Hy is dit op grond daarvan dat $\mathrm{Hy}$ skeppingsmiddelaar was deur wie God geskep het (1: 16a, 16c), en ook op grond daarvan dat die skepping in Hom sy integrasiepunt vind (1: 17b) en dat die skepping inderdaad daar is vir Hom, dit wil sê, bestaan tot sy verheerliking (Bratcher \& Nida 1977: 24-25). (Dit beteken dat ek met Botha 1986: 243, saamgaan ten opsigte van sy analise van die oorsaak-gevolgverhouding by sy items 3 en 4, maar nie by items 11 en 12 nie, waar die verhouding presies dieselfde is as by 3 en 4, en dus net andersom lê as wat volgens sy siening die geval is.)

- Ten opsigte van die kerk word die status van die Seun eweneens in terme van rangorde geteken. Ook hier is $\mathrm{Hy}$ eerste in rang: $\mathrm{Hy}$ is Hoof van die kerk; $\mathrm{Hy}$ is die Begin; $\mathrm{Hy}$ was die eerste om uit die dood op te staan (1: 18). Hierdie voorrang van die Seun word in 1: 19 en 20 onderskeidelik aan twee oorsaaklikhede toegeskryf. Vers 19 stel dat God dit goedgedink het dat sy volle wese in die Seun sou woon en vers 20 dat $\mathrm{Hy}$ dit goedgedink het dat alle dinge met Hom versoen sou word deur die vrede wat die Seun deur sy kruisdood bewerk het. Dat hierdie Seun, wat God is, deur sy sterwe die versoening bewerk het, maak Hom die belangrikste in die kerk. Daarom is Hy die Begin of Bron waaruit die kerk ontspring, soos ook daarin uitkom dat $\mathrm{Hy}$ die eerste was om uit die dood op te staan. Daarom is Hy ook Hoof van die kerk, sowel die Oorsprong wat as Representant die lede van die kerk by Hom geïnkorporeer en hulle sy liggaam gemaak het, asook die regeerder wat oor hulle bewind voer (vgl Du Plessis 1962: 90-115; Roberts 1963: 92-108).

Om nou sinvol oor die funksie van hierdie belydenis ten opsigte van die brief as geheel te kan oordeel, moet daar op enkele aspekte van die briefopset gewys word. Van direkte belang vir die vraag na die funksie van die oorgangsbelydenis is die toegevoegde verduideliking in 1: 21-23 oor die betekenis van die belydenis vir die ontvangers. Anders 
as by Efesiërs maak hierdie verduideliking egter nog nie deel uit van die briefliggaam nie, maar word dit opgevolg deur verdere oorgangsparagrawe (1: 24-2: 5) wat as uitdrukkings van 'n persoonlike aard en 'n 'lesers moet weet'-gedeelte die funksie het om die lesers toeganklik te stel vir die kommunikasie wat gaan volg. Dit beteken dat die briefliggaam by 2: 6 ' $\mathrm{n}$ aanvang neem met 'n vermaning en dat die hele liggaam van hierdie brief uit vermanings bestaan: Die brief is geskryf om die lesers teen die agtergrond van 'n ontwikkelende dwaalleer te vermaan om in die lig van die belydenis oor God se heilswerk in Christus, hulle ervaring van daardie heil en die hoë status van Christus as die met God wesens-eense Seun, as God se skeppingsmiddelaar wat eerste in rang staan teenoor die ganse skepping en as lewensbron en Hoof van die kerk - om in die lig van dié belydenis reg te gaan lewe sonder om aan die eise van die dwaalleer toe te gee. Met die oog hierop word daar in die vermanende hoofdeel teruggegryp op die belydenis, op die gelowiges se lewenskeuse vir Christus en die gepaardgaande oorgang tot die nuwe lewenstaat (2: 6-7), asook op die status van Christus as wesens-een met God en as kosmokrator wat oor alle magte heers en deur wie hulle die heil deelagtig geword het (2: 9-10 en herhaaldelik daarna, byvoorbeeld $2: 20 ; 3: 1 ; 3: 13 ; 4: 1$ ).

Ten opsigte van die funksionaliteit van die belydenis soos hier verstaan, kan gepas met 'n verwysing na Käsemann ([1949] 1960: 48-49) afgesluit word:

Der Grund für die Aufnahme dieser Liturgie an dieser Stelle kann ... nicht mehr fraglich sein ... . Die kolossische Gemeinde ist von der Irrlehre bedroht. Diese Irrlehre muss abgewehrt werden. Sie wird abgewehrt, indem der Antithesis die Thesis, der Polemik und Paränese das Bekenntnis der Gemeinde vorangestellt wird.

In al drie die gevalle wat hier ondersoek is, het dit geblyk dat die oorgangsbelydenisuitsprake (soos dit die geval is met die ander oorgangstegnieke) beslis funksioneel is ten opsigte van die briefkommunikasie. Enersyds sinjaleer dit sake van belang waaraan die outeur wil aandag skenk. Andersyds lê dit in wesenlike sin die grondslag vir die argument wat hy wil voer, vir die boodskap wat hy wil kommunikeer. Telkens is dit die geloofsoortuigings van die vroeë kerk waarmee die outeur hom vereenselwig deur aan te haal of self te formuleer, en waarvan hy die verwagting koester dat ook sy lesers hulle as vanself sal 
vereenselwig, wat die grondslag vorm vir sy teologiese uiteensetting en etiese vermaning - enersyds dus die grondslag vir belering ten opsigte van mistastinge, andersyds vir oorreding ten opsigte van sowel die verstaan van die evangelie as die Christelike lewenspraktyk.

\section{Literatuurverwysings}

ALLEN, TG 1986. Exaltation and solidarity with Christ: Ephesians, 1.20 and 2.6. Journal for the study of the New Testament 28, 103-120.

BARKHUIZEN, JH 1985. Carmen Christianum: 'n Inleiding tot die Grieks-Christelike himnografie van die eerste ses eeue. Pretoria: N G Kerkboekhandel.

BARTH, M 1974. Ephesians: Introduction, translation and commentary on chapters $1-3$. New York: Doubleday.

BARTH, M 1982. Christ and all things, in Hooker, MD \& Wilson, SG (eds), Paul and Paulinism: Essays in honour of CK Barrett, 160-172. London: SPCK.

BARTH, M 1984. Traditions in Ephesians. NTS 30, 3-25.

BAUGH, SM 1985. The poetic form of Col 1: 15-20. WThJ 47,227-244.

BOTHA, J 1986. A stylistic analysis of the Christ hymn (Col 1: 15-20), in Petzer \& Hartin $1986,238-251$.

BRATCHER, RG \& NIDA, EA 1977. A translator's handbook on Paul's letters to the Colossians and to Philemon. Stuttgart: United Bible Societies.

BRUCE FF 1984. The 'Christ Hymn' of Colossians 1: 15-20. BS 141, 99-111.

CONZELMANN, H 1955. Was glaubte die frühe Christenheit? Schweizerische Theol Umschau 25, 61-74, in Conzelmann, H 1974, Theologie als Schriftauslegung: Aufsätze zum Neuen Testament, 106-119. München: Kaiser.

CONZELMANN, H 1962. Der Brief an die Epheser, in Die kleineren Briefe des Apostels Paulus. Göttingen: Vandenhoeck \& Ruprecht. (NTD 8.)

CULLMANN, O 1943. Die ersten christlichen Glaubensbekenntnisse. Zollikon: Evangelischer Verlag.

DANA, HE \& MANTEY, JR 1927. A manual grammar of the Greek New Testament. Toronto: Macmillan.

DODD, CH 1959. The epistle of Paul to the Romans. London: Collins.

DU PLESSIS, IJ 1962. Christus as Hoof van kerk en kosmos: 'n Eksegeties-teologiese studie van Christus se hoofskap veral in Efesiërs en Kolossense. Groningen.

GLOER, WH 1984. Homologies and hymns in the New Testament: Form, content and criteria for identification. Perspectives in Religious Studies 11, 115-132.

GNILKA, J 1971. Der Epheserbrief. Freiburg: Herder.

HAHN, F 1980. Bekenntnisformeln im Neuen Testament, in Unterwegs zur Einheit: Festschrift für Heinrich Stirnimann, 200-214. Freiburg.

HAVENER, 1 1981. The pre-pauline christological credal formulae of 1 Thessalonians, in Richards, KH (ed) 1981, Society of Biblical Literature seminar papers, 105-128.

HENGEL. M 1983. Hymns and christology, in Between Jesus and Paul: Studies in the earliest history of Christianity, 78-96. London: SCM.

KÄSEMANN. E [1949] 1960. Eine urchristliche Taufliturgie, in Exegetische Versuche und Besinnungen, erster Band, 34-51. Göttingen: Vandenhoeck \& Ruprecht.

KÄSEMANN, E 1973. An die Römer. Tübingen: Mohr.

KOSKENNIEMI, H 1956. Studien zur ldee und Phraseologie des griechischer Briefes bis 400 $n$ Chr. Helsinki: Akateeminen Kirjakauppa.

LINDEMANN. A 1975. Die Aufhebung der Zeit: Geschichtsverständnis und Eschatologie im Epheserbrief. Gütersloh: Mohn.

LOHSE, E 1977. Die Briefe an die Kolosser und an Philemon. 2. Aufl. Göttingen: Vandenhoeck \& Ruprecht. 
LONA, HE 1984. Die Eschatologie im Kolosser- und Epheserbrief. Würzburg: Echter Verlag. MARTIN, RP 1972. Colossians: The church's Lord and the Christian's liberty. Exeter: Paternoster.

MCCOWN, W 1979. The hymnic structure of Colossians 1: 15-20. EvQ 51, 156-162.

MICHEL, O 1963. Der Brief an die Römer. 12. Aufl. Göttingen: Vandenhoeck \& Ruprecht. NEUFELD, VH 1963. The earliest Christian confessions. Leiden: Brill.

NORDEN, E 1956. Agnostos Theos: Untersuchungen zur Formengeschichte religiosër Rede. Stuttgart: Teubner.

PELSER, GMM 1984. Die brief aan die Romeine, in Du Toit, AB (red) 1984, Handleiding by die Nuwe Testament, Band 5: Die Pauliniese briewe: Inleiding en teologie, 41-56. Pretoria: N G Kerkboekhandel.

PETZER, JH \& HARTIN, PJ (eds) 1986. A South African perspective on the New Testament: Essays by South African New Testament scholars presented to Bruce Manning Metzger during his visit to South Africa in 1985. Leiden: Brill.

RIDDERBOS, H 1959. Aan de Romeinen. Kampen: Kok.

RIDDERBOS, H 1960. Aan de Kolossenzen. Kampen: Kok.

ROBERTS, JH 1963. Die opbou van die kerk volgens die Efese-brief. Groningen.

ROBERTS, JH 1983. Die brief aan die Efesiërs. Kaapstad: N G Kerk-Uitgewers.

ROBERTS, JH 1986a. Transitional techniques to the letter body in the corpus paulinum, in Petzer \& Hartin 1986, 187-201.

ROBERTS, JH 1986b. The eschatological transitions to the Pauline letter body. Neotestamentica 20, 29-35.

SANDERS, JT 1965. Hymnic elements in Ephesians 1-3. ZNW 56, 214-232.

SCHLIER, H 1958. Der Brief an die Epheser: Ein Kommentar. 2. Aufl. Düsseldorf: Patmos.

SCHNACKENBURG, $\mathrm{R}$ 1982. Der Brief an die Epheser. Zürich: Benziger Verlag.

SCHWEIZER, E 1980. Der Brief an die Kolosser. Zürich: Benziger Verlag.

VAWTER, B 1971. The Colossians hymn and the principle of redaction. CBQ 33, 62-81. WENGST, K 1967. Christologische Formeln und Lieder des Urchristentums. Bönn.

ZIMMERMANN, H 1968. Neutestementliche Methodenlehre: Darstellung der historischkritischen Methode. 2. Aufl. Stuttgart: Kath Bibelwerk. 